\title{
Agroclimatic effects on milk production and sub-clinical mastitis prevalence in dairy cattle
}

\author{
H. Susanty 1,2,*, B.P. Purwanto ${ }^{3}$, M. Sudarwanto ${ }^{4}$ and A. Atabany ${ }^{5}$ \\ ${ }^{1}$ Department of Animal Production and Technology, Faculty of Animal Science, \\ Andalas University, Padang 25163 - Indonesia \\ ${ }^{2}$ Graduate School Faculty of Animal Science, Bogor Agricultural University, \\ Jl. Raya Darmaga, Kampus IPB Darmaga Bogor 16680 - Indonesia \\ ${ }^{3} I P B$ Vocational College, Bogor Agricultural University, \\ Jl. Kumbang 14 Cilibende, Bogor 16155 - Indonesia \\ ${ }^{4}$ Department of Animal Diseases and Veterinary Public Health, Faculty of Veterinary Medicine, \\ Bogor Agricultural University, Jl. Agatis, Darmaga Campus, Bogor 16680 - Indonesia \\ ${ }^{5}$ Departemen of Animal Production and Technology, Faculty of Animal Sciences, \\ Bogor Agricultural University, Jl. Agatis, Darmaga, Bogor 16680 - Indonesia \\ *Corresponding E-mail: hildasusanty@gmail.com
}

Received June 06, 2018; Accepted August 20, 2018

\begin{abstract}
ABSTRAK
Penelitian ini bertujuan untuk mempelajari efek agroklimat terhadap produksi susu dan prevalensi mastitis subklinis sapi perah FH lokal di daerah tropis, Indonesia. Penelitian dilakukan pada dua ketinggian lokasi peternakan $<1000$ mdpl dan $\geq 1000$ mdpl di Jawa Barat. Data diperoleh dari 133 peternakan sapi perah rakyat dengan kepemilikan 3 - 10 ekor sapi perah laktasi, sapi-sapi dalam masa laktasi normal sebanyak 1150 kwartir dari 336 ekor. Parameter penelitian adalah kondisi agroklimat yang direpresentasikan sebagai Temperature Humidity Index (THI), konsumsi pakan, produksi susu, kualitas susu dan prevalensi mastitis subklinis. Hasil penelitian ini menunjukkan bahwa THI pada ketinggian $<1000 \mathrm{~m}$ dpl adalah 76.1-76.7 yang berakibat stres panas ringan pada ternak. Sementara THI pada ketinggian $\geq 1000 \mathrm{~m}$ dpl adalah 66.2-66.8 merupakan kondisi yang nyaman bagi sapi perah. Perbedaan yang signifikan ditemukan pada konsumsi pakan $(\mathrm{P}<0,01)$, produksi dan kualitas susu $(\mathrm{P}<0,05)$ antara dua ketinggian lokasi penelitian. Produksi susu pada ketinggian $\geq 1000 \mathrm{~m} \mathrm{dpl} 2.3 \mathrm{~kg}$ lebih tinggi dibanding pada $<1000 \mathrm{~m}$ dpl. Terdapat perbedaan status kesehatan ambing sapi-sapi perah pada kedua lokasi. 51\% sampel kwartir pada ketinggian $<1000$ mdpl terdeteksi mastitis subklinis (MSK) (kategori tinggi), sementara pada ketinggian $\geq 1000 \mathrm{~m}$ dpl hanya $42 \%$ (kategori sedang). Disimpulkan bahwa kondisi agroklimat yang direpresentasikan sebagai THI mempengaruhi kenyamanan sapi-sapi perah, yang berdampak pada tingkat produksi susu dan prevalensi mastitis sub-klinis.
\end{abstract}

Kata kunci: agroklimat, THI, produksi susu, mastitis sub-klinis, sapi perah

\section{ABSTRACT}

The present study was done to observe effect of agroclimate on milk production and prevalence of sub-clinical mastitis of local Holstein-Friesian dairy cattle in Indonesian small holder dairy farms. The research side were located in Region of $<1000$ masl and $\geq 1000 \mathrm{~m}$ above sea level (asl) in west Java. Data were obtained from 133 small holder dairy farms included 336 dairy cows in normal lactation period. Parameters observed were agro-climate condition, feed consumption, milk production and milk quality, and sub-clinical mastitis prevalence. Result sowed that THI at $<1000 \mathrm{~m}$ asl had a range of 76.1- 
76.7 leads to mild heat stress, while THI at $\geq 1000 \mathrm{~m}$ asl had a range of $66.2-66.8$ which makes comfort environment to the dairy cow. Differences in feed consumption $(\mathrm{P}<0.01)$, milk production and quality $(\mathrm{P}<0.05)$ were found among two altitude study location. Milk production at $\geq 1000 \mathrm{~m}$ asl was $2.3 \mathrm{~kg}$ higher than at $<1000 \mathrm{~m}$ asl. The udder health status was also different, a $51 \%$ of total sample at $<1000$ masl was detected sub-clinical mastitis (SCM) as high criteria, while $42 \%$ samples that were collected at $\geq 1000 \mathrm{~m}$ asl detected sub-clinical mastitis as middle criteria. In conclusion, agro-climate condition (THI) affect animal's comfort, milk production and sub-clinical mastitis prevalence.

Keywords: agroclimate, THI, milk production, sub-clinical mastitis, dairy cattle

\section{INTRODUCTION}

Productivity of dairy cattle is determined by genetic, environment, and interactions of both factors. Determinant genetic factor is breed while environmental factor includes feed management, climate, altitude, disease, pregnancy, calving interval, month of lactation and parity (Tyler and Ensminger, 2006). Altitudes of dairy farming location are attributable to dairy cattle production performance as milk production in lowlands is lower than in highlands (Nugroho et al., 2010). Milk yield of FH in lowlands $(<1000$ masl) was 1900 to $2100 \mathrm{~kg}$ per year whereas dairy cattle in highland produced $5800 \mathrm{~kg}$ milk per year. This is reasonable as highlands provide a favourable agro-ecology for milk production (Quiroz et al., 1997).

Some studies reported that milk production and reproduction of dairy cattle are affected by climate as high temperature lead to heat stress (Kadzere et al., 2002; West, 2003; Hansen, 2007). Degree of changes of body temperature above normal ranges indicates level of heat stress in dairy cattle. This is due to the combination affect of humidity, dry temperature, wind speed and solar radiation (Dikmen and Hansen, 2009).

An environmental temperature of below $23^{\circ} \mathrm{C}$ and humidity of $68 \%$ is ideal for the best production performance of dairy cattle (Bohmanova et al., 2007). Interactions of temperature and humidity index (THI) regulate comfort zone of dairy cattle. Atrian and Shahryar (2012) concluded the severity of heat stress as mild (72-78), moderate (79-88), severe (89-98), very severe (more than 98). According to Johnson (1985) and Du Preez et al. (1990) milk production is affected by heat stress. When mean THI values are above 72 , feed intake and milk production begin to decline, and continue to decline sharply at a THI value 76 or greater (Gorniak et al., 2014). Brügemann et al. (2012) mentioned that a unit increase in THI reduced milk production of
0.08 to $0.26 \mathrm{~kg}$. It is also reported that a greater THI is associated with changes in milk composition, milk somatic cell counts and mastitis prevalence (Hammami et al., 2013).

Lambertz et al. (2014) reported that heat stress attributable to an increase in somatic cell counts that is defined as sub-clinical mastitis prevalence. The occurance of sub-clinical mastitis at lowlands is reported to be 1.7 times higher than that of highland. (Biffa et al., 2005). This is because the animals in lowlands are at risk of experiencing heat stress. As a result, the animal sensitivity to the infection increased (Norman et al., 2000; Hammami et al., 2013).

Sub-clinical mastitis prevalence in dairy cattle in Indonesia is significantly high, this is responsible for a low milk production Tyler and Ensminger (2006). At the end of 2006, subclinical mastitis was reported to affect $75-83 \%$ of total dairy cattle population in Indonesia (Sudarwanto et al., 2006).

Information of dairy cattle productivity and udder health in highland and lowland farms is scarce. Therefore, this study aimed to evaluate the effect of agroclimate on milk production and prevalence of sub-clinical mastitis in Indonesian small holder dairy farms.

\section{MATERIALS AND METHODS}

\section{Research Design}

This research was conducted in dairy farms of West Java located in lowlands $(<1000 \mathrm{~m}$ asl) and highlands $(\geq 1000 \mathrm{~m}$ asl $)$. The lowlands research areas were dairy farms in Bogor (Kranggan, Cibungbulang), Sumedang and Sukabumi districts. While the highland research areas were dairy farms in_Bandung, Bandung Barat, Garut dan Kuningan and Bogor (Ciawi).

The data were collected from 133 small holder dairy farms who keep three to ten dairy cattle per farmer. In the area of $<1000 \mathrm{~m}$ asl there were 36 farms, while in the $\geq 1000 \mathrm{~m}$ asl there 
were 97 farms. Data were collected by survey method. Sub-clinical mastitis test was performed on 1351 quartile cow's milk samples from 336 milking cows ( 85 in $<1000 \mathrm{~m}$ asl and 251 in $\geq 1000 \mathrm{~m}$ asl area). Sample size determined based on the formula described by Martin et al. (1987). Somatic cell count calculation was done by Breed method (Sudarwanto, 2012). Parameters of milk quality were fat, protein and solid non-fat contents. Feed sampling was conducted in order to calculate the dry matter intake at each study area.

\section{Research Parameters}

Environmental Condition. Data of temperature and humidity index (THI) from 2006 to 2015 of below and upper of $1000 \mathrm{~m}$ above sea level (asl) study area were obtained from Meteorological, Climatological and Geophysical Station (BMKG) of Darmaga Bogor and Lembang, respectively. The agroclimate condition of THI was calculated using 2006-2015 climatologal data according to NRC formula (1971).

Milk Production. The milking process was conducted twice daily in the morning and in the afternoon. Recording of milk yield was conducted for one lactation period during sampling days in 2015. Samples of milk were analyzed for protein, fat and somatic cell count. Milk yield was recorded as 4\% FCM (fat corrected milk) .

Dry Matter Intake. Leftover feed were wighed and recorded to calculate individual dry matter intake of dairy cattle on each farm in $<1000 \mathrm{~m}$ asl $(\mathrm{n}=36)$ and $\geq 1000 \mathrm{~m}$ asl $(\mathrm{n}=96)$ every day for 2 sampling days ( $2 \times 24$ hours). Analysis of feed ingredients, dry matter, crude protein and crude fiber were done according to AOAC (1990).

Sub-clinical Mastitis Test. Sub-clinical mastitis test was performed using IPB-1 on 1351 milk quarter samples of 336 dairy cows. Milk samples were milked and a $2 \mathrm{ml}$ sample was added into four-chambered paddle. Immediately, a two $\mathrm{ml}$ reagent was put into the sample and homogenized by shaking for 15-20 seconds. Viscosity changes of milk samples and reagent IPB-1 mixture determined sub-clinical mastitis state. The results were reported as negative (-) if the mixture was homogenous, positive one $(+)$ if there was a thin gel, positive two $(++)$ if a thicker gel was formed, positive three $(+++)$ if there was gelatin-like substance were observed (Sudarwanto, 2012).
Somatic Cell Count. A modified Prescott and Breed (1910) method was used to count the somatic cell of each quarter. Milk samples was homogenized prior to the test. After that, a 0.01 $\mathrm{ml}$ of milk samples was placed to object glass by using pipette. It was smeared to the object glass and was dried for 5 to 10 minutes. Finally, it was fixed with Bunsen burner. The object glass was stained with blue methylene löfler for 1-2 minutes and was washed with $96 \%$ alcohol. Somatic cell count was conducted by using a microscope (100x) acording to Schalm et al. (1971).

Milk Quality Test and IgG measurement. Milk samples were collected twice a day in the morning and in the afternoon and were analyzed for milk fat content, protein and solid-non fat. Milk fat was measured by using Gerber method (Sudarwanto 2012). The calculation of milk protein content referred_to Sudarwanto (2012).

Dry matter of milk was determined by drying at $102{ }^{\circ} \mathrm{C}$ and estimated according to Fleischmann's formula (Vogt and Labuschagne, 1960). Milk samples were analyzed for IgG using ELISA according to Burgess (1988).

\section{Data Analysis}

Data during 2016-2015 were used to analyzed the changes of climate, but there was no climate change in 2015. Data were analyzed descriptively (environmental condition, chemical composition of diet). A T-test was used to analyzed_the difference of parameters (dry matter intake, milk production, milk quality, immunoglobulin $\mathrm{G}$ concentration and somatic cell count) at two different altitudes of research locations. Data was processed using MS Excel 2010 and Minitab 16.

\section{RESULTS AND DISCUSSIONS}

\section{Environmental condition}

The air temperature in West Java increased in the last decade (Figure 1). Based on data of air temperature from 2006 to 2015, it was revealed that there were increases in air temperature from $0.1^{\circ}$ to $2.0^{\circ} \mathrm{C}$. This is attributable to increases in THI. THI was an indicator of animals' comfort. Increasing in THI causes heat stress that negatively affects production performance, reproduction and health status.

Values of THI in the altitude of $<1000 \mathrm{~m}$ above sea level was fluctuated over time. The 

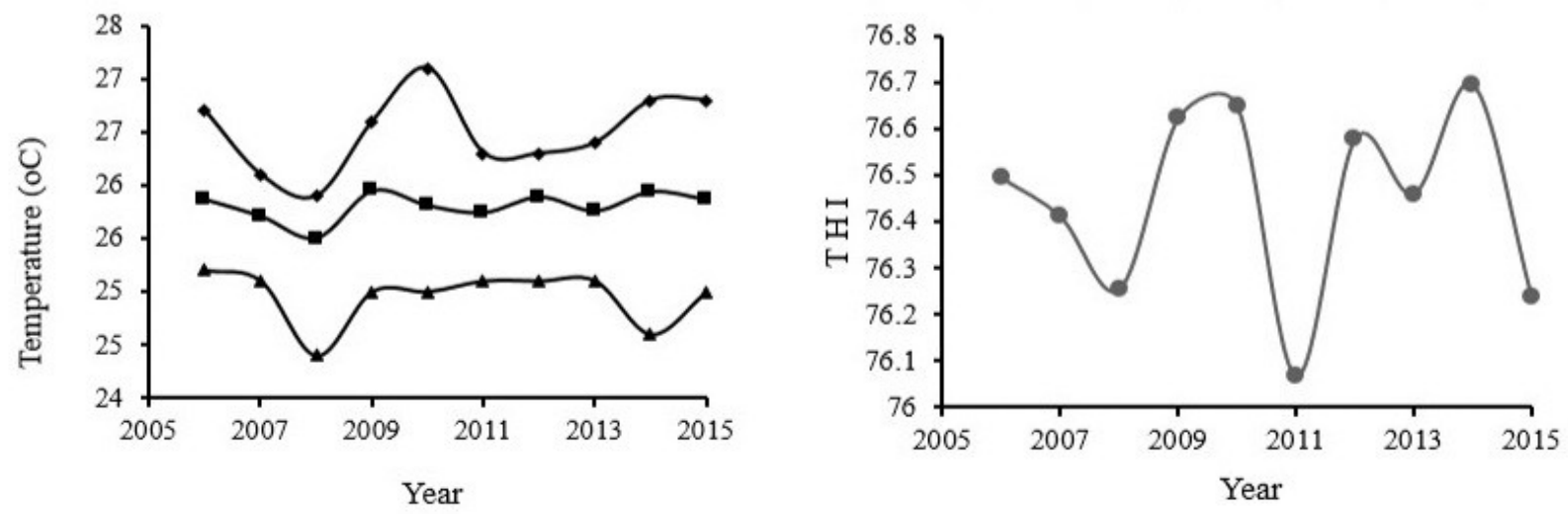

Figure 1. Temperature Changes for 10 Years in $<1000 \mathrm{~m}$ asl of West Java (Dramaga Station). The

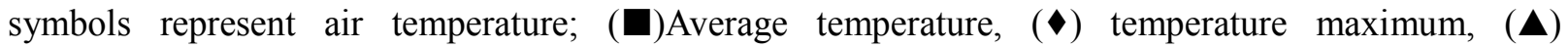
temperature minimum, and $(\bullet)$ temperature humidity index $(\mathrm{THI})$.

Source : BMKG (2017)

lowest THI was 76.1 and the highest was 76.7 . Data of THI from 2006 to 2015 showed that dairy cattle in this study area was under mild stress. Heat stress indicators (THI as environmental indicator) assists farmers to keep the animals in comfort zone and minimize negative effects of heat stress by spraying the animal during heat stress (Nickerson, 2014).

Altitude has inverse effect to temperature. Environmental traits in highlands are low temperature, high rainfall and high humidity levels. Agroclimate conditions are closely related to physiological responses of dairy cattle. Ideal air temperature and humidity are vital to support animal productivity (Biffa et al., 2005).

Average air temperature in the study area of $\geq 1000 \mathrm{~m}$ asl was $19.5-21.1^{\circ} \mathrm{C}$ with the THI of 66.2-66.8 (Figure 2). Temperature and humidity are climatic factors that cause changes in body temperature, water intake, energy balance and animal behavior as indicators of heat stress. A comfort zone set at THI of $<72$ is a situation when dairy cattle expresses maximum production performance (Atrian and Shahryar, 2012).

Increasing temperatures in these two study areas was due to changes in land use. Farms and plantations have transformed into more housing, less agricultural land and water catchment areas. Trees and vegetation are the determinants of changes in air temperature, since trees can reduce air temperatures from 0.86 to $5.15^{\circ} \mathrm{C}$ (Ainy, 2012).

In addition, high temperature has negative effects on animal feed because it causes changes in leaf color. As a result, it reduces green leaf substances and increases inhibition activity of hormones in plant. These negative effects are atributable to a low quality of forages, digestibility and productivity of dairy cattle.

Environmental factor such as temperature, humidity, solar radiation and velocity and interaction of those factors are attributable to production performance of dairy cattle (West, 2003). Altitude differences result in different production performances of Friesien Holstein. Interaction between temperature and relative humidity affects temperature and humidity index (THI). THI is used widely as thermal condition and the best predictor for heat stress in livestock (Bohmanova et al., 2007; Dikmen and Hansen, 2009). THI is closely associated with a decrease in milk production and milk protein level. This is in agreement with Brügemann et al. (2012) that reported a decrease in milk production as a result of heat stress due to differences in dairy farm location. This study showed that differences in THI led to differences in milk production, milk fat and solid-nonfat levels.

A level of THI that over the ambient temperature results in alterations of physiological responses to maintain homeostasis state. A natural response to encounter heat stress is to increase respiration rate, change in animal behavior, as well as increase water intake. However, the increase in water intake causes a decrease in dry matter intake (Atrian and Shahryar, 2012).

\section{Dry Matter Intake, Milk Production and Milk Composition}

Most farmers located in $<1000 \mathrm{~m}$ asl study 

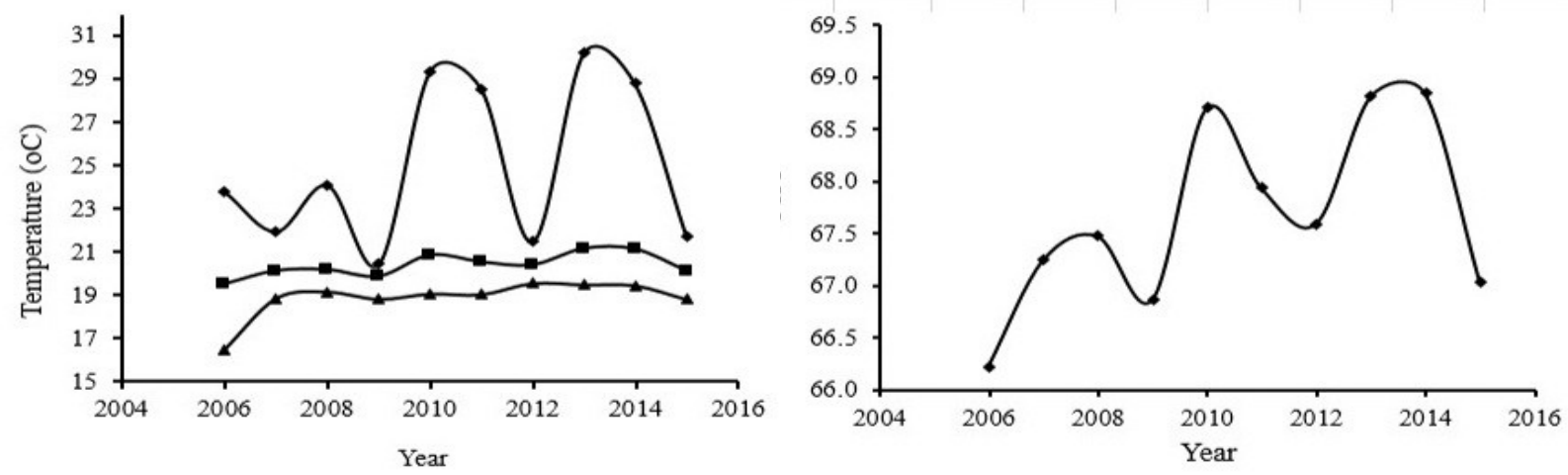

Figure 2. Temperature Changes for 10 Years in $\geq 1000 \mathrm{~m}$ asl of West Java (Lembang Station). The

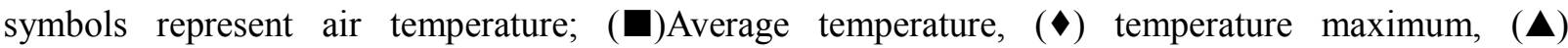
temperature minimum, and $(\bullet)$ temperature humidity index $(\mathrm{THI})$.

Source : BMKG (2017)

area fed dairy cattle with high percentage of forage. A minority of farmers fed the dairy cattle with good quality of grasses. The quantity and quality of forages were fluctuated over time. Chemical composition of diet in two altitudes is presented in Table 1.

Tofu waste supplementation as much as 2-7 $\mathrm{kg}$ dry matter was given in study area of $<1000 \mathrm{~m}$ asl. In contrast, a lower amount of tofu waste (1$1.5 \mathrm{~kg}$ dry matter) was given in $\geq 1000 \mathrm{~m}$ asl study area. Supplementation tofu waste aims to meet the nutritional adequacy of dairy cattle, because the forage provided by the farmer in lowland was a field grass with low nutritional quality. Chemical composition of diet in both study areas were different. Study area of $\geq 1000 \mathrm{~m}$ asl had a higher quality of diets compared to the lower altitude. Feeding high quality diets aims to fulfill nutrient requirement for maintenance, growth and production.

The result in Table 2 showed a significant $(\mathrm{P}<0.01)$ agroclimatic effect on DMI and milk production $(\mathrm{P}<0.05)$. Dry matter intake of dairy cattle located in $<1000 \mathrm{~m}$ asl was $7.82 \mathrm{~kg}$ and milk production was $13.9 \mathrm{~kg}$.day ${ }^{-1}$. According to NRC (2001), it showed that there was a shortage of $\pm 2.38 \mathrm{~kg}$ in dry matter intake. A low milk production in dairy cattle under heat stress was due to low dry matter intake as reported by Bouraoui et al. (2002). The reduction in feed intake and decline in milk production are consistent responses to heat stress in lactating dairy cow (Beede and Collier, 1986; Du Preez, 2000). In addition, Schnier et al. (2003) reported that milk production of dairy cattle was higher in a comfortable environmental temperature compared to that in cold environmental temperature. Optimum production performance of dairy cattle is achievable in warm, dry and comfortable environment. Environmental condition below and upper the comfort zone leads to health disorder and affects productivity (Webster, 1993).

Milk quality tests was conducted using fresh milk samples in the morning and afternoon. Results showed that there was no difference in milk protein and solid non fat in both study areas $(\mathrm{P}>0.05$; Table 3$)$. However, diet significantly affected milk fat $(\mathrm{P}<0.05)$.

Immunoglobulin is part of whey protein with concentration on colostrum reaching $100 \mathrm{~g} . \mathrm{l}^{-1}$, but the concentration of immunoglobulin decreases more than $1 \mathrm{~g} .1^{-1}$ for a week after partus (Fox, 2003). In addition, Batavani et al. (2007) mentioned that more than $80 \%$ of immunoglobulins in milk are Immunoglobulin $G$ (IgG). The results of this study showed that there was no difference in IgG concentration of milk between the two altitudes. Results of studies by Lambertz et al. (2014) support this study. In general, a decrease in milk protein was due to low dry matter intake and microbial protein synthesis in the rumen (Sutton, 1989). Results of this study showed that solid-non fat of milk from cattle raised in $<1000 \mathrm{~m}$ asl study area was lower than that in $\geq 1000 \mathrm{~m}$ asl study area. However, milk fat was higher in $<1000 \mathrm{~m}$ asl study area. Akers (2002) mentioned that milk production has a negative correlation with milk fat. This explains a higher milk production and low milk fat in $\geq 1000$ 
Table 1. Chemical Composition of Diets Given in Different Altitudes

\begin{tabular}{|c|c|c|c|c|}
\hline \multirow{3}{*}{ Diet } & \multicolumn{4}{|c|}{ Altitude ( $\mathrm{m}$ above sea level) } \\
\hline & \multicolumn{2}{|c|}{$<1000$} & \multicolumn{2}{|c|}{$\geq 1000$} \\
\hline & Forage & Concentrate & Forage & Concentrate \\
\hline & \multicolumn{4}{|c|}{ DM \% } \\
\hline Ash & 8.5 & 8.0 & 10.8 & 12.1 \\
\hline Crude Protein & 4.8 & 8.9 & 8.1 & 11.3 \\
\hline Crude Fiber & 37.9 & 17.2 & 32.8 & 14.5 \\
\hline Extract Ether & 1.1 & 4.3 & 1.2 & 6.8 \\
\hline NFE & 47.7 & 61.7 & 47.1 & 55.3 \\
\hline TDN & 48.1 & 62.7 & 49.2 & 67.8 \\
\hline
\end{tabular}

Table 2. Dry Matter Consumption and Milk Production of Dairy Cattle Raised in Different Altitudes of West Java

\begin{tabular}{lccc} 
& \multicolumn{2}{c}{ Altitude } & P-Value \\
\cline { 2 - 3 } & $<1000$ masl & $\geq 1000$ masl & \\
\hline Dry matter intake $\left(\mathrm{kg} . \mathrm{d}^{-1}\right)$ & $7.82 \pm 1.05$ & $12.49 \pm 1.07$ & 0.000 \\
$\quad$ - Forage & $2.66 \pm 1.42$ & $8.98 \pm 1.07$ & 0.000 \\
- Concentrate & $5.16 \pm 1.73$ & $3.51 \pm 1.11$ & 0.000 \\
Milk production $\left(\mathrm{kg}\right.$. day $\left.^{-1}\right)$ & $13.9 \pm 3.6$ & $16.2 \pm 3.4$ & 0.010 \\
4\% FCM (kg.d $\left.\mathrm{d}^{-1}\right)$ & $12.6 \pm 4.3$ & $15.1 \pm 3.7$ & 0.019 \\
Feed efficiency (kg FCM per kg DMI) & 1.6 & 1.2 & \\
\hline
\end{tabular}

m asl study area.

Heat stress is highly associated with physiological responses to encounter heat stress in dairy cattle. Thermoregulation responses in dairy cattle in handling heat stress affected health status of dairy cattle. Hammami et al. (2013) reported effects of THI on milk composition and somatic cell count that indicate health state of udder. Results showed that percentage of quarters with sub-clinical mastitis in $<1000 \mathrm{~m}$ asl study area was higher than that in $\geq 1000 \mathrm{~m}$ asl study area (Figure 3).

Imunoglobulin $\mathrm{G}$ ( $\mathrm{IgG}$ ) measurement on dairy cattle of both study areas showed that the average $\operatorname{IgG}$ was over $3.94 \mathrm{mg} / \mathrm{ml}$ and $3.85 \mathrm{mg} / \mathrm{ml}$ in lowlands and highlands, respectively. Batavani et al. (2007) stated that changes in milk $\operatorname{IgG}$ concentration is coupled with an increase in california mastitis test (CMT) score. A quarter detected positive 1 sub-clinical mastitis $(+)$ changes immunoglobulin concentration by $11.7 \%$ and continues to increase up to $48.20 \%$ with CMT score of positive $3(+++)$ (Batavani et al., 2007). Immunoglobulin has some important function such as prevention of bacterial invasion on epithelium membrane, inhibition on bacterial multiplication, and toxic neutralization. Main function of imunoglobulin is to prevent fagocytic microorganism (Batavani et al., 2007). The availability of blood amino acid affects 
Table 3. Composition and concentration IgG of milk in different altitudes of west Java

\begin{tabular}{lccc}
\hline \multirow{2}{*}{ Composition } & \multicolumn{2}{c}{ Altitude } & \multirow{2}{*}{ P-value } \\
\cline { 2 - 3 } & $<1000$ masl & $\geq 1000$ masl & \\
\hline Protein (\%) & $2.82 \pm 0.31$ & $2.88 \pm 0.46$ & 0.498 \\
Fat (\%) & $3.51 \pm 0.78$ & $3.06 \pm 1.09$ & 0.028 \\
SNF (\%) & $7.98 \pm 0.71$ & $8.10 \pm 1.04$ & 0.302 \\
Immunoglobulin G (mg.ml $\left.{ }^{-1}\right)$ & $3.94 \pm 1.90$ & $3.85 \pm 1.47$ & 0.790 \\
\hline
\end{tabular}

SNF: Solid non fat

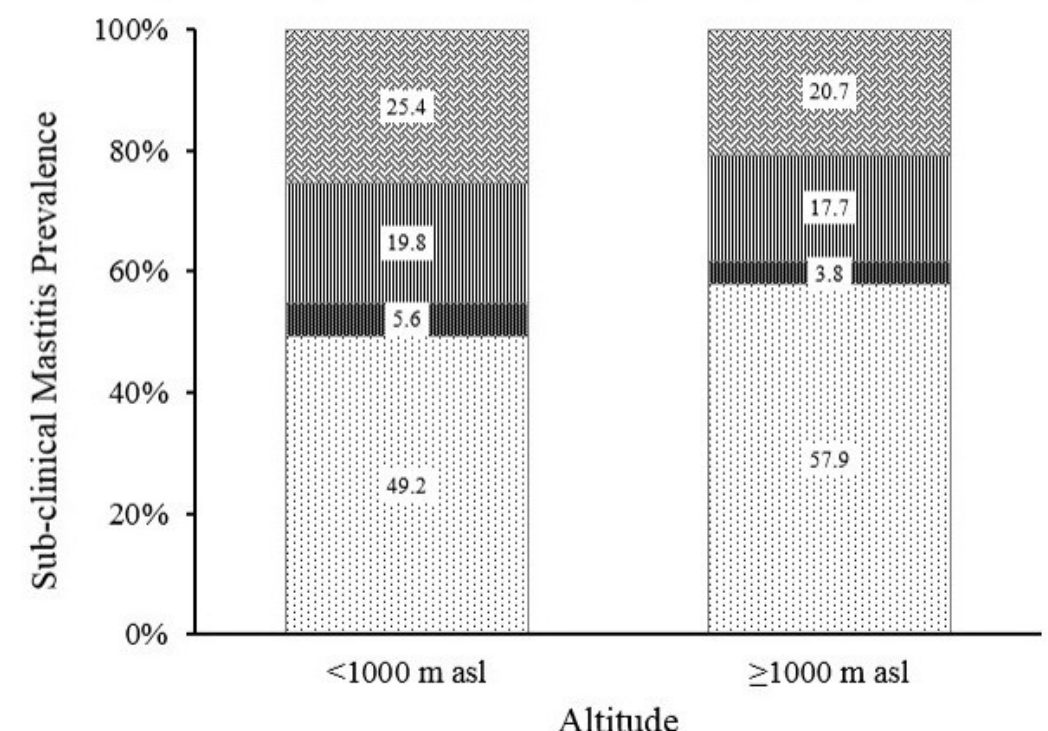

Figure 3.Sub-clinical Mastitis Prevalence in Dairy Farm in Two Altitudes of West Java. The symbols represent the result of sub-clinical mastitis test ( : : $)$

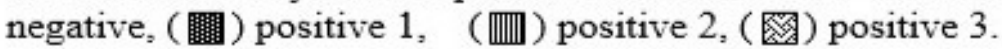

lymphocyte in $\mathrm{IgG}$ synthesis. Synthesis of $\mathrm{IgG}$ is possible by supply of dietary protein and amino acid in the rumen to balance amino acid in the blood. Body immune system has passive or active reaction against foreign bodies (Batavani et al., 2007).

\section{Subclinical Mastitis Prevalence}

Milk samples collected from 1334 quarters of 336 lactating dairy cattle were tested for subclinical mastitis test. The results showed that $50.8 \%$ quarters located in study area of $<1000 \mathrm{~m}$ asl were positive sub-clinical mastitis 1,2 and 3 . However, a lower percentage of quarters samples (42.1\%) were positive sub-clinical mastitis 1,2 and 3 in $\geq 1000 \mathrm{~m}$ asl study area. Acording to Susanty (2018), sub-clinical prevalence in $<1000$ $\mathrm{m}$ asl was classified as high prevalence, while those in $\geq 1000 \mathrm{~m}$ asl was middle. Overall, the percentage of positive sub-clinical mastitis 3 was higher than positive sub-clinical mastitis 2 and 1 in both altitudes.

The results of intensive research in some dairy centers in West Java showed the prevalence of sub-clinical mastitis reached $70.99 \%$ (Pisestyani, 2017). In general, sub-clinical mastitis prevalence at $<1000 \mathrm{~m}$ asl was $8.7 \%$ higher compared with dairy cows at $\geq 1000$ masl (Figure 3). This was affected by many factors included warmer environmental conditions, less 
Table 4. Somatic Cell Count of Lowland and Highland Milk Samples (cells/ml)

\begin{tabular}{lrrr}
\hline \multirow{2}{*}{ IPB-1 test } & \multicolumn{2}{c}{ Altitude } & P-value \\
\cline { 2 - 3 } & \multicolumn{1}{c}{$<1000$ masl } & $\geq 1000$ masl & \\
\hline Positive 1 & $214743 \pm 180261$ & $233833 \pm 106304$ & 0.769 \\
Positive 2 & $555904 \pm 289795$ & $575440 \pm 344572$ & 0.822 \\
Positive 3 & $1039920 \pm 903000$ & $1618080 \pm 951000$ & 0.013 \\
\hline
\end{tabular}

feed consumption, and lower feeding quality.

Dairy cow's udder health status can be seen from subclinical mastitis test. The result of subclinical mastitis test using IPB-1 reagent is an indirect subclinical mastitis test. Severity of subclinical mastitis is determined by alteration in gel formation as a result of IPB-1 reagents and milk samples reactions. The results of this test are supported with calculation of somatic cells present in milk. Table 4 shows a significant difference in the number of somatic milk cells in a positive sub-clinical mastitis was 3 in IPB-1 test $(\mathrm{P}<0.05)$; however, the number of somatic cells in the positive sub-clinical mastitis test 1 and 2 in IPB-1 test was similar.

Somatic cell count measured in milk secreted in early lactation until week $5^{\text {th }}$ and $6^{\text {th }}$ was higher. It decreased and reached normal state in week $30^{\text {th }}$ to $33^{\text {rd }}$. Somatic cell count began to increase in week $36^{\text {th }}$ to week $41^{\text {st }}$ or in the beginning of dry period (Nielsen, 2009). Somatic cell count is the most important indicator to determine level of infection or inflammation in udder. Results of this study showed that an increase in somatic cell count led to higher subclinical mastitis score analyzed by using IPB-1 reagent (Table 4). An infection of positive 3 observed in $<1000 \mathrm{~m}$ asl was $4.7 \%$ higher than that of $\geq 1000 \mathrm{~m}$ asl research site.

The number of somatic cell is the best indicator for health status of udder infected by mastitis (Olde Riekerink et al., 2007). Results of this study showed that sub-clinical mastitis prevalence was higher in $<1000 \mathrm{~m}$ asl study area with the THI of $>72$. Udder detected as positive 3 was different from udder labelled positive 2 and 1 . Bouraoui et al. (2002) stated that somatic cell score increased as environmental temperature significantly increase at late spring to summer. In addition, increases in somatic cell score is also reported in dairy cattle raised in pens (Barkema et al., 2013).

The number of somatic cells is also affected by other factors such as parity, lactation, management, type of animal housing and environmental conditions such as air temperature, humidity and seasons (Alhussien and Dang, 2018). Another study conducted by Simensen (1976) found that the seasonal relationship with somatic cell numbers was not only caused by environmental conditions, but also the effect of different dairy cattle management systems.

\section{CONCLUSION}

Agroclimate condition (THI) affects milk production and sub-clinical mastitis prevalence. Dairy cows located in $\geq 1000 \mathrm{~m}$ asl produces 2.3 $\mathrm{kg}$ milk higher than that of dairy cows in $<1000 \mathrm{~m}$ asl. In term of sub-clinical mastitis, prevalence was higher by $8.7 \%$ in $<1000 \mathrm{~m}$ asl study area.

\section{REFERENCES}

Ainy, C.N. 2012.Pengaruh Ruang Terbuka Hijau terhadap Iklim Mikro di Kawasan Kota Bogor. Thesis. Bogor Agricultural University.

Akers, R.M. 2002. Lactation and The Mammary Gland, First Ed. United State: Animal Iowa State Press. New York

Alhussien, M.N. and A.K. Dang. 2018. Milk somatic cells, factors influencing their release, future prospects, and practical utility in dairy animals: An overview. Vet. World. 11(5):562-577.

AOAC. 1990. Association of Official Analytical Chemist, Official methods of analysis, 14th ed., Washington, DC.

Atrian, P. and H.A. Shahryar. 2012. Heat stress in dairy cows (a review). Res. Zool. 2(4):3137.

Barkema, H.W., S. De Vliegher, S. Piepers and 
R.N. Zadoks. 2013. Herd level approach to high bulk milk somatic cell count problems in dairy cattle. Vet. Quarterly. 33(2): 82-89.

Batavani, R.A., S. Asri and H. Naebzadeh. 2007. The effect of subclinical mastitis on milk composition in dairy cows. Iranian J. Vet. Res. 8(3):205-211.

Beede, D. and R. Collier. 1986. Potential Nutritional Strategies for Intensively Managed Cattle during Thermal Stress. J. Anim. Sci. 62(2): 543-554.

Biffa, D, E. Debela and F. Beyene. 2005. Prevalence and risk factors of mastitis in lactating dairy cows in Southern Ethiopia. Int. J. Appl. Res. Vet. Med. 3(3):189-198.

Bohmanova, J., I. Misztal and J. Cole. 2007. Temperature-humidity indices as indicators of milk production losses due to heat stress. J. Dairy.Sci. 90:1947-1956.

Bouraoui, R., M. Lahmar, A. Majdoub, M. Djemali and R. Belyea. 2002. The relationship of temperature-humidity index with milk production of dairy cows in a Mediterranean climate. Anim Res. 51:479491.

Brügemann, K., E. Gernand, U. König von Borstel and S. König. 2012. Defining and evaluating heat stress thresholds in different dairy cow production systems. Arch Tierz. 55(1):13-24.

Burgess, G.W. 1988. ELISA technology in diagnosis and research. Graduate School of Tropical Veterinary Science, James Cook University of North Queensland, Townsville, Australia.

Dikmen, S. and P.J. Hansen. 2009. Is the temperature-humidity index the best indicator of heat stress in lactating dairy cows in a subtropical environment? J Dairy Sci. 92(1):109-116.

Du Preez, J., W. Giesecke and P. Hattingh. 1990. Heat stress in dairy cattle and other livestock under southern African conditions. I. Temperature-humidity index mean values during the four main seasons. Onderstepoort J. Vet Res. 57:77-87.

$\mathrm{Du}$ Preez, J.H. 2000. Parameters for the determination and evaluation of heat stress in dairy cattle in South Africa. Onderstepoort J. Vet. Res. 67:263-71.

Fox PF. 2003. The Milk Protein. Developments in dairy chemistry-4. Functional Milk Protein. Elsevier Applied Science. London and New York
Gorniak T, Meyer U, Südekum K-H, Dänicke S. 2014. Impact of mild heat stress on dry matter intake, milk yield and milk composition in mid-lactation Holstein dairy cows in a temperate climate. Arch. Anim. Nutr. 68(5):358-369.

Hammami, H., J. Bormann, N. M'Hamdi, H.H. Montaldo and N. Gengler. 2013. Evaluation of heat stress effects on production traits and somatic cell score of Holsteins in a temperate environment. J. Dairy Sci. 96(3): 1844-55.

Hansen, P.J. 2007. Exploitation of genetic and physiological determinants of embryonic resistance to elevated temperature to improve embryonic survival in dairy cattle during heat stress. Theriogenology. 68(1):S242-S249.

Johnson, H.D. 1985. Physiological Responses and Productivity of Cattle, in: Yousef M.K. (Ed.), Stress Physiology in livestock. Basic Principles. Florida: CRC Press. p. 4-19.

Kadzere C, Murphy M, Silanikove N, Maltz E. 2002. Heat stress in lactating dairy cows: a review. Livest. Prod. Sci. 77(1):59-91.

Lambertz, C., C. Sanker and M. Gauly. 2014. Climatic effects on milk production traits and somatic cell score in lactating HolsteinFriesian cows in different housing systems. J. Dairy Sci. 97(1):319-329.

Martin, S., A. Meek and P. Willeberg. 1987. Veterinary Epidemiology: Principle and Methods. Iowa State University Pr. 343 p. Iowa (US)

Nickerson, S.C. 2014. Manajemen Strategies to Reduce Heat Stress, Prevent Mastitis and Improve Milk Quality in Dairy Cows and Heifers. UGA Extension Bulletin 1426. The University of Georgia.

Nielsen, C. 2009. Economic impact of mastitis in dairy cows. Uppsala: Swedish University of Agricultural Science.

Norman, H.D., R.H. Miller, J.R. Wright and G.R. Wiggans. 2000. Herd and State Means for Somatic Cell Count from Dairy Herd Improvement. J. Dairy Sci. 83:2782-2788.

NRC. 2001. Nutrient Requirement of Dairy Cattle. National Academi Press. Washington, DC

Nugroho, A.T.K., P. Surjowardojo and M.N. Ihsan. 2010. Penampilan produksi sapi perah friesien holstein $(\mathrm{FH})$ pada berbagai paritas dan bulan laktasi di ketinggian tempat yang berbeda. JIIPB. 20(1):55-64. 
Olde Riekerink, R.G., H.W. Barkema and H. Stryhn. 2007. The effect of season on somatic cell count and the incidence of clinical mastitis. J. Dairy Sci. 90(4):17041715.

Pisestyani, H. 2017. Pengembangan Prototipe Alat Celup Puting untuk Pencegahan Mastitis Subklinis pada Sapi Perah di Indonesia . Dissertation. Bogor Agricultural University.

Quiroz, R.A., D. Pezo, D.H. Rearte and F.R. San Martin. 1997. Dynamics of feed resources in mixed farming systems of Latin America. Crop residues in sustainable mixed crop/livestock farming systems. International Crop Research Institute for the Semi-Arid Tropics, Andhra Pradesh (India). No. 0851991777.

Schalm, O.W., E.J. Carroll and N.C. Jain. 1971. Bovine mastitis. Lea \& Febiger.

Schnier, C., S. Hielm and H.S. Saloniemi. 2003. Comparison of milk production of dairy cows kept in cold and warm loose-housing systems. Prev. Vet. Med. 61(4): 295-307.

Simensen, E. 1976. Milk somatic cells in dairy cows kept on pasture or confined indoors during the summer. Nord. Vet. Med. 28
(12):603-609.

Sudarwanto, M. 2012. Pemeriksaan Susu dan Produk Olahannya. IPB Press.

Sudarwanto M, Latif H, Noordin M. 2006. The Relationship of The Somatic Cell Counting to sub-clinical Mastitis and to Improve Milk Quality. 1st International AAVS Scientific Conference. Jakarta, July 12-13, 2006.

Susanty H. 2018. Evaluasi Penerapan Aspek Teknis dan Sebaran Spasial Produksi Susu dan Prevalensi Mastitis Subklinis Sapi Perah Rakyat di Jawa Barat. Disertation. Bogor Agricultural University.

Sutton JD. 1989. Altering milk composition by feeding. J Dairy Sci. 72: 2801-2814.

Tyler HD, Ensminger ME. 2006. Dairy Cattle Science. Fourth Edition. Upper Saddle River, New Jersey.

Vogt KF, Labuschagne JH. 1960. The Accuracy of the density method for the determination of solids-non-fat in milk. South African J. Agric. Sci.. 3:395-402.

Webster, J. 1993. Understanding the Dairy Cow. Blackwell Scientific Publications. Oxford

West, J.W. 2003. Effects of heat-stress on production in dairy cattle. J. Dairy Sci. 86: 2131-2144. 